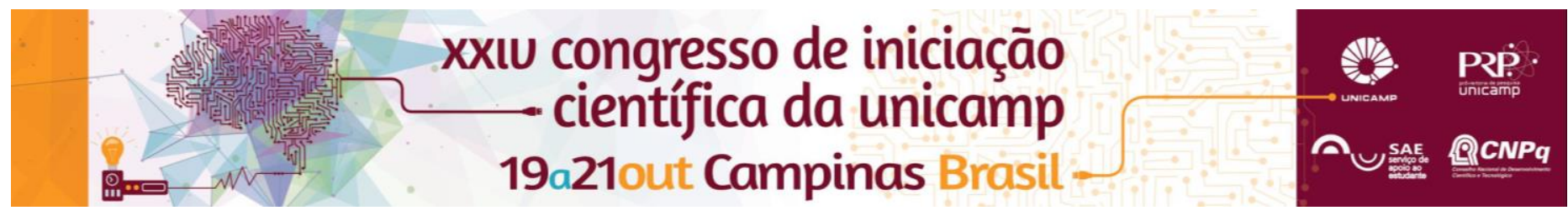

\title{
Gilberto Freyre e os Antagonismos em Equilíbrio: revisitando o debate deste conceito com sua fortuna crítica
}

\section{Luísa Maria Rutka Dezopi*}

\begin{abstract}
Resumo
A partir de Casa-Grande \& Senzala e Sobrados e Mucambos de Gilberto Freyre, este projeto de pesquisa se propõe a analisar as características do conceito de "antagonismos em equilíbrio" e revisitar o debate entre tal conceito e seus principais comentadores, promovendo assim a compreensão de temas como miscigenação e cultura, e proporcionando discussões sobre o debate intelectual das décadas de 1920 e 1930.
\end{abstract}

\section{Palavras-chave: \\ Identidade Nacional, Antagonismos em Equilíbrio, Gilberto Freyre.}

\section{Introdução}

O Brasil via-se no momento histórico das décadas de 1920 e 1930 numa complexa e importante conjuntura de transição política, econômica e cultural, fazendo-se necessário que a sociedade se mobilizasse em prol de novos projetos políticos. Desta forma, instaurou-se um debate intelectual nas obras dos ensaístas das décadas de 1920 e 1930 cujo principal caráter era a ampliação das discussões sobre a questão da cultura e a busca da identidade nacional, a fim de promover reflexões sobre as possíveis relações entre o Estado e a Sociedade. Os ensaístas, desta forma, buscam inventar a cultura a fim de legitimar o processo de invenção da identidade nacional, retomando o debate sobre raça e civilização'. Nesse cenário, encontram-se principalmente José Antonio Nogueira e sua defesa do bovarismo; Sérgio Buarque de Holanda e o estudo das raízes históricas do Brasil; Paulo Prado e sua argumentação a favor de um realismo; Oliveira Vianna, o problema do caráter mimético da cultura brasileira e o arianismo; Vicente Licínio Cardoso e um nacionalismo conservador e pouco progressista; e Gilberto Freyre e o caráter positivo da miscigenação.

Considerando este último ensaísta, Gilberto Freyre, de importante destaque no debate intelectual por conta de sua reviravolta teórica e positiva acerca do conceito de miscigenação no Brasil, este trabalho tem por objetivo investigar o constructo fundamental para a compreensão de suas teses nas obras Casa-Grande \& Senzala e Sobrados e Mucambos: antagonismos em equilíbrio, e estabelecer diálogo com a fortuna crítica do autor, revisitando o debate atual sobre tal conceito e seus principais comentadores.

\section{Resultados e Discussão}

Tendo em vista que Gilberto Freyre não reservou uma seção ou capítulo em suas obras para tratar especificamente dos antagonismos em equilíbrio, um conceito sobre este tema somente pode ser inferido através da análise e junção de descrições distribuídas no decorrer de suas obras, de forma qualitativa e através de análises de conteúdo.

Na obra Casa Grande \& Senzala, Gilberto Freyre afirmou a importância da relação etnia e cultura, resgatou o papel do negro enquanto escravo na construção da sociedade brasileira e modificou a ideia de mestiçagem, redefinindo-a com o interesse de reinventar a identidade brasileira ${ }^{2}$. Em Sobrados e Mucambos, o autor discutiu o processo de decadência do patriarcalismo no Brasil e a quebra de sua acomodação, o mulato enquanto ator social, e a constituição de novas relações de dominação e subordinação ainda baseadas na manutenção dos antagonismos em equilíbrio. De forma geral, esta obra sustentou a argumentação de Casa Grande \& Senzala e forneceu os pilares da noção de mudança social com vista nos antagonismos em equilíbrio promovidos pela unidade da família ${ }^{3}$.

\section{Conclusões}

A maior contribuição de Gilberto Freyre para as pesquisas brasileiras foi sua compreensão da hierarquia como um ponto central do sistema social brasileiro, dado que possibilitava a articulação das diversidades, promovendo a conciliação de conflitos, contrastes e antagonismos em equilíbrio. A noção de antagonismos em equilíbrio converteu-se em uma das três principais características que definem a tradição cultural brasileira. Isto é, juntamente com as paixões nas relações sociais pertencentes ao patriarcado que, mesmo com todos os antagonismos, geravam uma atmosfera de intimidade; e com as influências externas europeias, constituindo-se numa sociedade que absorve e colide com diferentes culturas, permanecendo em equilíbrio e evitando sua própria destruição; os antagonismos em equilíbrio revelam ser um argumento central para a correta compreensão do período colonial, não podendo ser restringidos a somente uma categoria de classificação, pois permeia todas elas, ocupando nas mesmas uma função importante para o acontecimento e manutenção dos fatos.

\section{Agradecimentos}

Agradeço ao Conselho Nacional de Desenvolvimento Científico e Tecnológico (CNPq) pelo apoio financeiro e pela concessão de bolsas; ao professor orientador do projeto de iniciação científica Mário Augusto Medeiros da Silva e aos pesquisadores do grupo de estudos "Pensamento Social do Brasil"; e à minha família.

\footnotetext{
1 BASTOS, Elide Rugai. As Criaturas de Prometeu. Gilberto Freyre e a formação da sociedade brasileira. São Paulo: Global Editora, 2006.

2 FREYRE, Gilberto. Casa-Grande \& Senzala. São Paulo: Editora Global, 2013, $52^{\mathrm{a}}$ ed.

${ }^{3}$ FREYRE, Gilberto. Sobrados e Mucambos. São Paulo: Editora Global, 2006 $16^{\mathrm{a}}$ ed.
} 